\title{
TINGKAT KEPATUHAN WAJIB PAJAK UMKM DI JAWA TIMUR, INDONESIA
}

\author{
Setiadi Alim Lim \\ Program Studi Akuntansi Politeknik Ubaya \\ Jalan Ngagel Jaya Selatan 169, Surabaya \\ setiadi.alim@gmail.com \\ Lilik Indrawati \\ Program Studi Manajemen \\ Fakultas Ekonomi Universitas Katolik Darma Cendika \\ Jalan Dr. Ir. H. Soekarno 201, Surabaya \\ lilik.indrawati.2013@gmail.com
}

\begin{abstract}
Micro, small and medium-sized enterprises play an important role in national economic development in many countries around the world. Micro, small and medium-sized enterprises have a large contribution to GDP (Gross Domestic Product), the supply of employment and exports of a country. Although it has a large contribution to the national economy, the contribution of micro, small and medium-sized enterprises to the state income from the tax sector is very small. There is a tendency for voluntary tax compliance from micro, small and mediumsized enterprises to be very low. This research aims to study the level of micro, small and medium-sized enterprises of tax compliance in East Java, Indonesia. To measure the level of tax compliance, 3 indicators are used, namely the ownership of the Taxpayer Identification Number (TIN), compliance with paying Income Tax and compliance to fill out and report the Annual Income Tax Return. The results showed that the level of tax compliance in micro, small and medium enterprises in East Java, Indonesia was still very low. Micro, small and medium-sized who have a Taxpayer Identification Number (TIN) is only 37.80\%, those who pay Income Tax are only $21.95 \%$ and those who fill and report Annual Income Tax Returns of only $18,29 \%$.
\end{abstract}

\footnotetext{
ABSTRAK

Usaha mikro, kecil dan menengah memegang peranan penting dalam pembangunan ekonomi nasional pada banyak negara di seluruh dunia. Usaha mikro, kecil dan menengah mempunyai kontribusi yang besar pada GDP (Gross Domestic Product), penyediaan lapangan kerja dan ekspor suatu negara. Walaupun mempunyai kontribusi besar terhadap ekonomi nasional, namun kontribusi usaha mikro, kecil dan menengah terhadap pemasukan negara dari sektor pajak sangat kecil. Ada kecenderungan tingkat kepatuhan pajak dari usaha mikro, kecil dan menengah yang bersifat sukarela (voluntary tax compliance)
} 
masih sangat rendah. Penelitian ini bertujuan untuk meneliti tingkat kepatuhan pajak usaha mikro, kecil dan menengah di Jawa Timur, Indonesia. Untuk mengukur tingkat kepatuhan pajak digunakan 3 indikator, yaitu kepemilikan Nomor Pokok Wajib Pajak (NPWP), kepatuhan membayar Pajak Penghasilan dan kepatuhan mengisi dan melaporkan Surat Pemberitahuan (SPT) Tahunan Pajak Penghasilan. Hasil penelitian menunjukkan tingkat kepatuhan pajak usaha mikro, kecil dan menengah di Jawa Timur, Indonesia masih sangat rendah. Wajib Pajak usaha mikro, kecil dan menengah yang mempunyai Nomor Pokok Wajib Pajak (NPWP) hanya sebesar 37,80\%, yang membayar Pajak Penghasilan hanya sebesar 21,95\% dan yang mengisi dan melaporkan Surat Pemberitahuan (SPT) Tahunan Pajak Penghasilan hanya sebesar 18,29\%.

Keywords: micro, small and medium enterprises, voluntary tax compliance, enforced tax compliance, intervention tax compliance.

\section{PENDAHULUAN}

Usaha mikro, kecil dan menengah (UMKM) memegang peranan penting dalam pembangunan ekonomi suatu negara. OECD (2015: 13) menyatakan di sebagian besar negara, usaha kecil dan menengah (UKM) mewakili lebih dari 95\% semua perusahaan. Usaha kecil dan menengah berkontribusi besar pada pencapaian tujuan dasar ekonomi nasional apa pun (Herman, 2012). Peran penting dari usaha kecil dan menengah antara lain adalah: (i) usaha kecil dan menengah dipandang sebagai aktor utama pembangunan nasional dan regional di banyak negara (Keskin et al., 2010); (ii) usaha kecil dan menengah (UKM) memiliki proporsi yang besar untuk menyerap tenaga kerja dan berkontribusi secara signifikan pada pertumbuhan ekonomi nasional dan global (OECD, 2015); (iii) usaha kecil dan menengah (UKM) adalah elemen yang dinamis dan memegang peranan penting dalam pengembangan ekonomi di seluruh dunia (Şentürk et al., 2008).

Menurut Atawodi and Ojeka (2012) sebagian besar perusahaan besar memiliki akar dalam usaha kecil dan menengah (UKM) yang menunjukkan bahwa perusahaan besar masa depan adalah usaha kecil dan menengah (UKM) hari ini yang harus dipelihara untuk memastikan pertumbuhannya. Hal ini menunjukkan bahwa perusahaan-perusahaan besar yang saat ini beroperasi dengan skala regional, nasional maupun transnasional hampir semuanya berasal dan bertumbuh dari usaha mikro, kecil dan menengah beberapa tahun lalu yang terus berkembang menjadi besar seperti saat ini. Karena itu kebanyakan pemerintah dari banyak negara memberikan dukungan yang sangat besar kepada usaha mikro, kecil dan menengah agar dapat lebih cepat bertransformasi menjadi perusahaan besar yang memiliki daya saing kuat agar mampu memberikan kontribusi yang besar bagi pertumbuhan ekonomi dan daya saing nasional.

Usaha kecil dan menengah (UKM) merupakan bagian utama dari ekonomi negara maju dan berkembang. Mereka berkontribusi pada pertumbuhan ekonomi dengan mencipta- 
kan lapangan kerja baru dan mendukung pembangunan ekonomi dan sosial yang seimbang. Karena kontribusi penting ini, banyak negara mengembangkan dan menerapkan kebijakan baru yang mendorong pembentukan, perluasan, pengembangan, dan perlindungan UKM (Başçı and Durucan, 2017).

Usaha mikro, kecil dan menengah menjadi motor pertumbuhan ekonomi, penyerapan tenaga kerja serta relatif lebih mempunyai resistensi yang tinggi terhadap hantaman badai krisis ekonomi dibandingkan dengan usaha skala besar. Karenanya pemerintahan hampir di semua negara memberikan perhatian yang besar terhadap pemberdayaan dan keberlangsungan eksistensi usaha mikro, kecil dan menengah.

Di negara-negara Uni Eropa usaha kecil dan menengah merupakan mesin dari ekonomi negara-negara Eropa. Mereka mendorong penciptaan lapangan kerja dan pertumbuhan ekonomi serta menjamin stabilitas sosial. Pada 2013, lebih dari 21 juta usaha kecil dan menengah menyediakan 88,8 juta pekerjaan di seluruh Uni Eropa. Sembilan dari setiap 10 perusahaan adalah usaha kecil dan menengah, dan usaha kecil dan menengah menghasilkan dua dari setiap tiga pekerjaan. Usaha kecil dan menengah juga merangsang semangat kewirausahaan dan inovasi di seluruh Uni Eropa dan dengan demikian penting untuk mendorong daya saing dan pekerjaan (European Commission, 2015: 3). Data dari European Commision ini menunjukkan peranan yang signifikan dari usaha kecil dan menengah di negara-negara Uni Eropa yang hampir seluruhnya merupakan negara-negara yang masuk kelompok negara-negara maju. Usaha kecil dan menengah ratarata menyediakan lapangan pekerjaan kurang lebih sebanyak 4 orang untuk setiap usaha kecil dan menengah. Kelihatannya jumlah tenaga kerja yang diserap untuk 1 usaha kecil dan menengah tidak terlalu besar, namun karena jumlah usaha kecil dan menengah jumlahnya sangat besar hampir sembilan kali lipat dari jumlah usaha besar, maka secara keseluruhan penyerapan jumlah tenaga kerja dari usaha kecil dan menengah menjadi sangat besar.

Di negara-negara Asia, usaha kecil dan menengah (UKM) memegang peranan yang sangat penting bagi pengembangan ekonomi di negaranegara Asia. Usaha kecil dan menengah adalah tulang punggung ekonomi Asia. Lebih dari 96\% semua bisnis di Asia merupakan usaha kecil dan menengah yang menyediakan dua dari tiga pekerjaan sektor swasta di benua ini (Yoshino and Hesary, 2017). Usaha kecil dan menengah (UKM) memberikan kontribusi yang signifikan bagi ekonomi Asia. Jumlah mereka sangat banyak, karena mereka mencakup 98\% atau lebih dari semua perusahaan di sebagian besar negara-negara di Asia (Vandenberg et al., 2013).

Tambunan and Feng (2008) menyatakan di negara-negara berkembang di Asia, usaha kecil dan menengah telah memberikan kontribusi yang signifikan selama bertahun-tahun yang diukur berdasarkan kontribusinya dalam: (a) jumlah perusahaan; (b) lapangan pekerjaan; (c) produksi dan nilai tambah; (d) GDP; (e) perusahaan yang didirikan oleh pengusaha perempuan; dan (f) penyebaran industri regional.

Bisnis dalam bentuk apa pun, ukuran atau sektor diwajibkan oleh hu- 
kum untuk mematuhi semua UndangUndang yang relevan termasuk perpajakan (Ponorica and Al-Saedi, 2015). Usaha mikro, kecil dan menengah wajib memenuhi kewajiban membayar pajak sesuai dengan Undang-Undang Perpajakan.

Mengingat jumlah usaha mikro, kecil dan menengah umumnya sangat banyak, maka kepatuhan dari usaha mikro, kecil dan menengah dalam memenuhi kewajiban perpajakannya memegang peranan yang sangat penting dalam memberikan kontribusi penerimaan negara dari sektor pajak. Hal ini seperti yang dinyatakan oleh Arachi and Santoro (2007) bahwa perpajakan usaha kecil dan menengah (UKM) selalu memainkan peran penting dalam sistem fiskal Italia. Hal senada disampaikan oleh Swistak (2016) yang menyatakan bahwa usaha kecil dan menengah (UKM) adalah bagian penting dari populasi pembayar pajak di negara manapun di seluruh dunia.

Walaupun jumlah dari usaha mikro, kecil dan menengah sangat besar, namun kontribusinya terhadap penerimaan negara, khususnya penerimaan dari sektor pajak relatif masih sangat kecil. Atawodi and Ojeka (2012) mengungkapkan bahwa kepatuhan pajak di kalangan usaha kecil dan menengah (UKM) buruk. Menurut Swistak (2016) usaha kecil dan menengah jumlahnya banyak, tetapi hanya berkontribusi sedikit pada penerimaan negara, sementara meraka sering menyerap sebagian besar sumber daya administrasi pajak yang langka dan sangat dibutuhkan di tempat lain dalam administrasi sistem pajak.

Keberhasilan suatu negara dalam meningkatkan kepatuhan usaha mikro, kecil dan menengah dalam membayar pajak akan sangat membantu dalam meningkatkan penerimaan negara dari sektor pajak untuk jangka pendek dan jangka panjang. Sebaliknya kegagalan suatu negara untuk meningkatkan kepatuhan pajak dari usaha mikro, kecil dan menengah untuk membayar pajak akan menyebabkan kesulitan untuk meningkatkan penerimaan dari sektor pajak dalam jangka pendek dan jangka panjang. Karena usaha mikro, kecil dan menengah saat ini di kemudian hari kemungkinan sudah berubah menjadi perusahaan besar. Ketidakpatuhan membayar pajak saat ini akan terbawa pada saat yang akan datang.

Mengingat pentingnya kepatuhan usaha mikro, kecil dan menengah untuk membayar pajak dalam rangka memberikan kontribusi optimal bagi penerimaan pajak dari sektor pajak, maka penelitian mengenai kepatuhan pajak dari usaha mikro, kecil dan menengah akan menjadi suatu studi yang menarik. Tulisan ini akan mencoba meneliti mengenai tingkat kepatuhan usaha mikro, kecil dan menengah di Jawa Timur, Indonesia, khususnya dalam membayar Pajak Penghasilan.

\section{TINJAUAN PUSTAKA \\ Definisi dan Kriteria Usaha Mikro, Kecil dan Menengah}

Banyak definisi yang dikemukakan mengenai usaha mikro, kecil dan menengah. Ada banyak indikator yang dipakai untuk memberikan definisi mengenai usaha mikro, kecil dan menengah, antara lain: jumlah penjualan, jumlah karyawan, jumlah nilai aset dan indikator-indikator lainnya. Menurut Keskin et al. (2010) batasan mengenai definisi usaha kecil dan menengah umumnya berubah-ubah sesuai dengan ukuran ekonomi dari suatu negara. Hal senada disampaikan oleh Adair and Taylor (1994) dalam 
Agbemava et al. (2016) yang menyatakan definisi usaha kecil dan menengah sangat bervariasi dan tidak pasti.

Walaupun definisi usaha mikro, kecil dan menengah sangat bervariasi antara satu pendapat dengan pendapat yang lain, antara satu komunitas dengan komunitas yang lain, antara satu negara dengan negara yang lain, antara satu wilayah dengan wilayah yang lain, antara satu tinjauan dan perspektif dengan tinjauan dan perspektif lain yang berbeda, serta definisi ini selalu berkembang dan berubah dari waktu ke waktu, namun secara umum ada beberapa indikator atau parameter yang dapat digunakan untuk membuat batasan atau definisi antara usaha mikro, usaha kecil, usaha menengah dan usaha besar.

Banyak definisi tidak menyebutkan adanya usaha mikro yang dianggap satu kesatuan dengan usaha kecil. Namun pembedaan antara usaha mikro dan kecil tetap sangat dibutuhkan, karena usaha mikro adalah usaha yang benar-benar sangat kecil dengan kemampuan yang sangat minimal dalam berbagai sudut, baik dari modal, jumlah penjualan, penghasilan, peralatan, tenaga kerja, manajemen dan teknologi serta kemampuan lainnya. Sedangkan usaha kecil relatif sudah lebih berdaya dibandingkan dengan usaha mikro.

Usaha mikro banyak ditemui dalam bentuk pedagang-pedagang kaki lima atau pedagang keliling yang tidak memiliki tempat yang tetap untuk menjalankan usahanya dengan jumlah penjualan dan jumlah penghasilan yang tidak menentu. Sedangkan usaha kecil umumnya sudah lebih baik dari usaha mikro yang bisa dilihat antara lain dari pedagang-pedagang yang sudah memiliki tempat atau kios kecil untuk berdagang dengan jumlah penjualan dan jumlah penghasilan yang relatif sudah mulai lebih pasti. Dalam struktur perekonomian, khususnya di negara-negara berkembang jumlah yang terbanyak adalah usaha dengan skala mikro dibandingkan usaha skala kecil, menengah ataupun besar. Kegagalan suatu negara dalam mengembangkan atau minimal memfasilitasi usaha mikro akan berdampak pada kegagalan usaha pemerintah untuk mengurangi jumlah kemiskinan dan dampak sosial lainnya seperti meningkatnya kriminalitas yang akan menimbulkan peningkatan gangguan keamanan dan keresahan sosial yang bisa berpengaruh pada hal-hal krusial lainnya.

Karena ini pengelompokkan dan definisi tersendiri usaha mikro yang terpisah dari usaha kecil akan sangat membantu terutama untuk dapat melakukan usaha-usaha pemberdayaan dan pengembangannya secara lebih fokus, khususnya di negara-negara berkembang. Keberhasilan dalam pengembangan usaha mikro akan dapat terlihat dari banyaknya usaha mikro yang naik kelas menjadi usaha kecil. Demikian pula keberhasilan dalam pengembangan usaha kecil akan terlihat dari banyaknya usaha kecil yang naik kelas menjadi usaha menengah. Kemudian keberhasilan pengembangan usaha menengah akan terlihat dari banyaknya usaha menengah yang naik kelas menjadi usaha besar. Pembinaan dan pengembangan usaha mikro, kecil dan menengah dengan cara berjenjang ini akan memudahkan pemerintah untuk melahirkan usaha-usaha besar yang mampu bersaing secara global.

Walaupun definisi atau batasan mengenai usaha mikro, kecil dan menenegah antara satu dan lain pendapat 
banyak berbeda, serta definisi dan batasan tersebut dapat berubah-ubah sejalan dengan waktu dan perubahan yang terjadi di bidang ekonomi dan bisnis, namun secara umum definisi atau batasan tersebut dapat ditinjau dari dua perspektif, yaitu definisi atau batasan kuantitatif dan definisi atau batasan kualitatif. Definisi atau batasan kuantitatif mengelompokkan usaha mikro, kecil dan menengah berdasarkan suatu kriteria atau parameter yang dapat dikuantifikasikan. Sedangkan definisi atau batasan kualitatif akan mengelompokkan usaha mikro, kecil dan menengah berdasarkan suatu kriteria atau parameter yang tidak dapat dikuantifikasikan. Untuk kemudahan pengelompokkan, maka definisi atau batasan kuantitatif akan lebih mudah untuk membedakan antara usaha mikro, kecil dan menengah.

Kriteria atau parameter yang banyak digunakan pada definisi atau batasan kuantitatif antara lain: jumlah penjualan, jumlah tenaga kerja, jumlah aset atau jumlah modal yang dimiliki dan kriteria atau parameter lainnya. European Commision (2015: 11) memberikan definisi kuantitatif mengenai usaha mikro, kecil dan menengah dengan menggunakan kriteria jumlah karyawan, penjualan tahunan atau jumlah nilai neraca tahunan seperti terlihat pada Tabel 1.

Tabel 1

Definisi Usaha Mikro, Kecil dan Menengah Menurut European Union Standards

\begin{tabular}{|c|c|c|c|c|}
\hline $\begin{array}{l}\text { Enterprise } \\
\text { Category }\end{array}$ & $\begin{array}{l}\text { Headcount: } \\
\text { Annual } \\
\text { Work Unit } \\
\text { (AWU) }\end{array}$ & $\begin{array}{l}\text { Annual } \\
\text { Turnover } \\
(€)\end{array}$ & \multirow{4}{*}{ OR } & $\begin{array}{c}\text { Annual Balance } \\
\text { Sheet Total (€) }\end{array}$ \\
\hline $\begin{array}{l}\text { Medium- } \\
\text { Sized }\end{array}$ & $<250$ & $\leq 50$ million & & $\leq 43$ million \\
\hline Small & $<50$ & $\leq 10$ million & & $\leq 10$ million \\
\hline Micro & $<10$ & $\leq 2$ million & & $\leq 2$ million \\
\hline
\end{tabular}

Definisi kuantitatif mengenai usaha mikro, kecil dan menengah dengan menggunakan kriteria yang kurang lebih sama yaitu jumlah karyawan, jumlah aset atau jumlah penjualan tahunan menurut World Bank dalam Berisha and Pula (2015) seperti terlihat pada Tabel 2.

Tabel 2

Definisi Usaha Mikro, Kecil dan Menengah Menurut World Bank

\begin{tabular}{|c|c|c|c|c|}
\hline $\begin{array}{l}\text { Enterprise } \\
\text { Indicators }\end{array}$ & $\begin{array}{l}\text { Number of } \\
\text { Employees }\end{array}$ & $\begin{array}{c}\text { Total Assets } \\
\text { (\$) }\end{array}$ & \multirow{4}{*}{ OR } & $\begin{array}{c}\text { Total Annual } \\
\text { Sales (\$) }\end{array}$ \\
\hline $\begin{array}{l}\text { Medium- } \\
\text { Sized }\end{array}$ & $\begin{array}{r}>50 \\
\leq 300 \\
\end{array}$ & $\begin{array}{l}>3 \text { million; } \\
\leq 15 \text { million }\end{array}$ & & $\begin{array}{l}>3 \text { million; } \\
\leq 15 \text { million }\end{array}$ \\
\hline Small & $\begin{array}{l}>10 \\
\leq 50 \\
\end{array}$ & $\begin{array}{l}>100.000 \\
\leq 3 \text { million } \\
\end{array}$ & & $\begin{array}{l}>100.000 \\
\leq 3 \text { million } \\
\end{array}$ \\
\hline Micro & $<10$ & $\leq 100.000$ & & $\leq 100.000$ \\
\hline
\end{tabular}

Sumber: Independent Evaluation Group (2008) dalam Berisha and Pula (2015)

Jika dibandingkan, definisi usaha mikro, kecil dan menengah menurut European Commission (2015: 11) dengan definisi dari World Bank ada perbedaan. Menurut European Commission (2015: 11) digolongkan usaha mikro, kecil dan menengah jika jumlah tenaga kerja $<250$ orang, jumlah penjualan $\leq$ $€ 50$ juta atau jumlah aset $\leq € 43$ juta, sedangkan menurut World Bank digolongkan usaha mikro, kecil dan menengah jika jumlah tenaga kerja $\leq$ 300 orang, jumlah penjualan $\leq$ US $\$ 15$ juta atau jumlah aset $\leq$ US\$15 juta.

OECD (2010) telah mengumpulkan data mengenai definisi usaha mikro, kecil, menengah dan besar yang bersifat kuantitatif menurut beberapa negara berdasarkan kriteria jumlah pekerja. Definisi kuantitatif tersebut seperti terlihat pada Tabel 3.

Tabel 3

Klasifikasi Besarnya Perusahaan per Negara Berdasarkan Jumlah Pekerja

\begin{tabular}{l} 
Berdasarkan Jumlah Pekerja \\
\begin{tabular}{|l|c|c|c|c|c|}
\hline & Micro & Small & Medium & SME & Large \\
\hline $\begin{array}{l}\text { EU countries, } \\
\text { Iceland, Norway } \\
\text { and Switzerland }\end{array}$ & $1-9$ & $10-49$ & $50-249$ & $1-249$ & $250+$ \\
\hline Australia & $0-9$ & $10-49$ & $50-199$ & $0-199$ & $200+$ \\
\hline Canada & $0-9$ & $10-49$ & $50-499$ & $0-499$ & $500+$ \\
\hline Japan & $4-9$ & $10-49$ & $50-249$ & $1-249$ & $250+$ \\
\hline Korea & $5-9$ & $10-49$ & $50-199$ & $5-199$ & $200+$ \\
\hline Mexico & $0-10$ & $11-50$ & $51-250$ & $1-250$ & $251+$ \\
\hline New Zealand & $1-9$ & $10-49$ & $50-99$ & $0-99$ & $100+$ \\
\hline Turkey & $1-19$ & $20-49$ & $50-249$ & $1-249$ & $250+$ \\
\hline United States & $1-9$ & $10-99$ & $100-499$ & $1-499$ & $500+$ \\
\hline
\end{tabular} Sumber: OECD (2010: 47) \\
\hline
\end{tabular}


Sedangkan definisi kualitatif salah satunya diberikan oleh UNIDO seperti yang dikemukakan oleh Yon and Evans (2011) pada Tabel 4.

Tabel 4

Definisi Kualitatif Usaha Mikro, Kecil dan Menengah Menurut UNIDO

\begin{tabular}{|c|c|c|c|}
\hline \begin{tabular}{|l|} 
No. \\
\end{tabular} & Category & SMEs & Large Companies \\
\hline 1. & Management & $\begin{array}{l}\text { Proprietor-en- } \\
\text { trepreneurship } \\
\square \text { Functions } \\
\text { linked to } \\
\text { Personalities }\end{array}$ & $\begin{array}{l}\text { Manager-entre- } \\
\text { preneurship } \\
\text { Division of Labor } \\
\text { by subject } \\
\text { matters }\end{array}$ \\
\hline 2. & Personnel & $\begin{array}{l}\text { Lack of uni- } \\
\text { versity } \\
\text { graduates } \\
\text { All-round } \\
\text { knowledge }\end{array}$ & 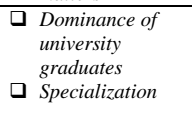 \\
\hline 3. & Organization & $\begin{array}{l}\text { Highly } \\
\text { Personalized } \\
\text { contacts }\end{array}$ & $\begin{array}{l}\text { Highly formalized } \\
\text { communication }\end{array}$ \\
\hline 4. & Sales & $\begin{array}{l}\text { Competitive } \\
\text { position not } \\
\text { defined and } \\
\text { uncertain }\end{array}$ & $\begin{array}{l}\text { Strong } \\
\text { competitive } \\
\text { position }\end{array}$ \\
\hline 5. & $\begin{array}{l}\text { Buyer's } \\
\text { Relationship }\end{array}$ & U Unstable & $\begin{array}{l}\text { Based on long } \\
\text { term contracts }\end{array}$ \\
\hline 6. & Production & $\begin{array}{l}\text { Labor } \\
\text { intensive }\end{array}$ & $\begin{array}{l}\text { Capital intensive, } \\
\text { economies of } \\
\text { scale }\end{array}$ \\
\hline 7. & $\begin{array}{l}\text { Research } \\
\text { Development }\end{array}$ & $\begin{array}{l}\text { Following the } \\
\text { market, intui- } \\
\text { tive approach }\end{array}$ & Institutionalized \\
\hline 8. & Finance & $\begin{array}{l}\text { Role of } \\
\text { family } \\
\text { funds, self } \\
\text { financing }\end{array}$ & $\begin{array}{l}\text { Diversified } \\
\text { ownership } \\
\text { structure, } \\
\text { access to } \\
\text { anonymous } \\
\text { capital market }\end{array}$ \\
\hline
\end{tabular}

\section{Usaha Mikro, Kecil dan Menengah di Indonesia}

Menurut IFC (2016) 99 persen dari semua perusahaan di Indonesia merupakan usaha mikro, kecil dan menengah (UMKM), mempekerjakan 89 persen tenaga kerja sektor swasta, dan menyumbang 57 persen kepada GDP (Gross Domestic Product) Indonesia. Peran vital dari usaha mikro, kecil dan menengah di Indonesia juga diungkapkan oleh Bellefleur et al. (2012) yang menyatakan bahwa usaha mikro, kecil dan menengah (UMKM) dan wiraswasta memainkan peran penting dalam perekonomian Indonesia. Usaha mikro, kecil dan menengah merupakan lebih dari 99 persen dari semua perusahaan di sektor ekonomi Indonesia dan mempekerjakan lebih dari 95 persen populasi.
Indonesia seperti negara-negara lainnya memiliki definisi atau kriteria sendiri dalam mengelompokkan usaha menjadi usaha mikro, kecil dan menengah. Klasifikasi usaha menjadi usaha mikro, kecil dan menengah diatur dalam Undang-Undang Nomor 20 Tahun 2008 tentang Usaha Mikro, Kecil dan Menengah (selanjutnya disebut Undang-Undang UMKM) pasal 6 ayat (1), ayat (2) dan ayat (3). UndangUndang UMKM melakukan pengelompokan usaha menjadi usaha mikro, kecil dan menengah berdasarkan kriteria jumlah penjualan dalam 1 tahun dan kekayaan bersih tidak termasuk tanah dan bangunan tempat usaha. Pengelompokkan usaha menjadi usaha mikro, kecil dan menengah tampak seperti Tabel 5.

Tabel 5

Definisi Usaha Mikro, Kecil dan Menengah Menurut Undang-Undang UMKM

\begin{tabular}{|l|c|c|c|}
\hline $\begin{array}{c}\text { Kelompok } \\
\text { Usaha }\end{array}$ & $\begin{array}{c}\text { Jumlah Kekayaan Bersih } \\
\text { Tidak Termasuk Tanah dan } \\
\text { Bangunan Tempat Usaha } \\
\text { (Rp.) }\end{array}$ & & $\begin{array}{c}\text { Jumlah } \\
\text { Penjualan } \\
\text { Tahunan } \\
\text { (Rp.) }\end{array}$ \\
\hline Mikro & $\leq 50$ juta & \multirow{4}{*}{ ATAU } & $\leq 300$ juta \\
\cline { 1 - 1 } & $>50$ juta dan $\leq 500$ juta & & $>300$ juta dan \\
& & $\leq 2,5$ milyar \\
& & & $>2,5$ milyar dan \\
& & $\leq 50$ milyar \\
\hline
\end{tabular}

Sumber: Undang-Undang Nomor 20 Tahun 2008 pasal 6 ayat (1), ayat (2) dan ayat (3)

Klasifikasi usaha menjadi usaha mikro, kecil dan menengah di Indonesia hanya menggunakan 2 kriteria tersebut di atas dan tidak menggunakan kriteria lainnya seperti jumlah karyawan yang banyak digunakan oleh negara-negara lain.

Pengelompokkan usaha menjadi usaha mikro, kecil dan menengah dibutuhkan oleh setiap negara agar bisa menetapkan fokus sasaran yang akan dibina, difasilitasi dan diberdayakan untuk dapat naik kelas pada kelompok usaha yang lebih tinggi. Data dari Kementerian Koperasi dan Usaha Kecil dan Menengah mengenai jumlah 
unit usaha mikro, kecil dan menengah di Indonesia pada tahun 2015 seperti terlihat pada Tabel 6 .

Tabel 6

Data Unit Usaha di Indonesia Tahun 2015

\begin{tabular}{|l|c|c|}
\hline \multicolumn{1}{|c|}{ Keterangan } & Jumlah (unit) & $\begin{array}{c}\text { Persentase } \\
\text { Jumlah (\%) }\end{array}$ \\
\hline Unit Usaha & 59.267 .759 & $100 \%$ \\
\hline $\begin{array}{l}\text { Usaha Mikro, Kecil } \\
\text { dan Menengah }\end{array}$ & 59.262 .772 & $99,99 \%$ \\
\hline Usaha Mikro & 58.521 .987 & $98,74 \%$ \\
\hline Usaha Kecil & 681.522 & $1,15 \%$ \\
\hline Usaha Menengah & 59.263 & $0,1 \%$ \\
\hline Usaha Besar & 4.987 & $0,01 \%$ \\
\hline
\end{tabular}

Sumber: Kementerian Koperasi dan Usaha

Kecil dan Menengah (2016: 12)

\section{Pajak Penghasilan untuk Usaha Mikro, Kecil dan Menengah di Indonesia}

Sebelum tahun 2013 usaha mikro, kecil dan menengah di Indonesia dapat memilih untuk menghitung $\mathrm{Pa}-$ jak Penghasilan yang menjadi kewajibannya dengan menggunakan Norma Perhitungan Penghasilan Neto. Untuk menggunakan Norma Perhitungan Penghasilan Neto, usaha mikro, kecil dan menengah harus melakukan pencatatan atas penjualan yang dilakukannya. Namun apabila usaha mikro, kecil dan menengah ingin menghitung Pajak Penghasilan tidak menggunakan Norma Perhitungan Penghasilan Neto, maka usaha mikro, kecil dan menengah harus melakukan pembukuan dan Pajak Penghasilannya dihitung dengan mengalikan tarif Pajak Penghasilan pasal 17 dengan Laba Bersih Kena Pajak.

Walaupun sudah disediakan fasilitas menghitung Pajak Penghasilan dengan menggunakan Norma Perhitungan Penghasilan Neto, namun usaha mikro, kecil dan menengah masih mengalami banyak kesulitan untuk dapat memenuhi kewajiban perpajakannya dengan baik. Merespon hal tersebut pada tahun 2013 Pemerintah menerbitkan Peraturan Pemerintah Nomor 46 Tahun 2013 tentang Pajak Penghasilan atas Penghasilan dari Usaha yang Diterima atau Diperoleh Wajib Pajak yang Memiliki Peredaran Bruto Tertentu, yang dimaksudkan untuk mempermudah usaha mikro, kecil dan menengah dalam memenuhi kewajiban perpajakannya. Menurut Peraturan Pemerintah Nomor 46 Tahun 2013, untuk usaha mikro, kecil dan menengah dikenakan Pajak Penghasilan yang bersifat final dengan tarif $1 \%$ dari peredaran bruto.

Peraturan Pemerintah Nomor 46 Tahun 2013 ini kemudian diganti dengan Peraturan Pemerintah Nomor 23 Tahun 2018 tentang Pajak Penghasilan atas Penghasilan dari Usaha yang Diterima atau Diperoleh Wajib Pajak yang Memiliki Peredaran Bruto Tertentu. Dalam pasal 3 ayat (1) Peraturan Pemerintah Nomor 23 Tahun 2018 menyebutkan Wajib Pajak yang memiliki peredaran bruto tertentu yang dikenai Pajak Penghasilan final adalah Wajib Pajak orang pribadi, Wajib Pajak badan berbentuk koperasi, persekutuan komanditer, firma atau perseroan terbatas yang menerima atau memperoleh penghasilan dengan peredaran bruto tidak melebihi Rp. 4.800.000.000,- dalam 1 tahun pajak. Pada pasal 5 ayat (1) Peraturan Pemerintah Nomor 23 Tahun 2018 disebutkan jangka waktu pengenaan Pajak Penghasilan bersifat final paling lama 7 tahun pajak bagi Wajib Pajak orang pribadi, 4 tahun pajak bagi Wajib Pajak badan berbentuk koperasi, persekutuan komanditer atau firma dan 3 tahun pajak bagi Wajib Pajak badan berbentuk perseroan terbatas. Mengenai besarnya tarif Pajak Penghasilan bersifat final yang dikenakan diatur dalam pasal 2 ayat (2) Peraturan Pemerintah Nomor 23 
Tahun 2018 yang menyebutkan tarif Pajak Penghasilan bersifat final yang dikenakan sebesar $0,5 \%$ dari jumlah peredaran bruto.

Adanya perlakuan khusus pengenaan Pajak Penghasilan bersifat final ini membantu memberikan kemudahan bagi usaha mikro, kecil dan menengah agar dapat melaksanakan kewajiban perpajakannya dengan baik dan benar. Namun seperti yang disebutkan dalam pasal 5 Peraturan Pemerintah Nomor 23 Tahun 2018, perlakuan khusus ini hanya berlaku dalam jangka waktu tertentu yaitu 7 tahun untuk Wajib Pajak orang pribadi dan 3 sampai dengan 4 tahun untuk Wajib Pajak badan. Hal ini menunjukkan bahwa dalam jangka panjang Pemerintah menginginkan usaha mikro, kecil dan menengah harus memenuhi kewajiban perpajakannya menggunakan mekanisme dan prosedur umum yang berlaku serta tidak memakai mekanisme dan perlakuan khusus.

Jadi perlakuan khusus pengenaan Pajak Penghasilan untuk usaha mikro, kecil dan menengah melalui Peraturan Pemerintah Nomor 46 Tahun 2013 dan Peraturan Pemerintah Nomor 23 Tahun 2018 dimaksudkan untuk memudahkan usaha mikro, kecil dan menengah memenuhi kewajiban perpajakannya dengan harapan akan meningkatkan kepatuhan Wajib Pajak usaha mikro, kecil dan menengah. Dalam jangka waktu seperti yang dimaksudkan dalam pasal 5 ayat (1) Peraturan Pemerintah Nomor 23 Tahun 2018 diharapkan usaha mikro, kecil dan menengah tersebut sudah patuh membayar pajak, sehingga perlakuan dan mekanisme khusus seperti yang diatur dalam Peraturan Pemerintah Nomor 23 Tahun 2018 tidak diperlukan lagi.

\section{Wajib Pajak Patuh}

Menurut Kirchler and Wahl (2010) kepatuhan pajak (tax compliance) mewakili istilah paling inklusif dan netral untuk kesediaan Wajib Pajak untuk membayar pajak. Namun, kepatuhan pajak dapat bersifat sukarela (voluntary tax compliance) atau ditegakkan oleh otoritas pajak (enforced tax compliance). Ketidakpatuhan mengacu pada kegagalan untuk memenuhi kewajiban perpajakan, baik disengaja ataupun tidak disengaja. Hasil ketidakpatuhan mungkin merupakan penghindaran pajak yang legal (tax avoidance) atau manipulasi pajak yang melanggar hukum pajak (tax evasion). Menurut Gitaru (2017) kepatuhan pajak mengacu pada kesediaan seorang Wajib Pajak untuk mematuhi aturan pajak di negaranya, misalnya dengan mendeklarasikan penghasilannya, menyampaikan Surat Pemberitahuan (SPT), dan membayar semua pajak yang jatuh tempo dengan tepat waktu.

Menurut OECD (2008: 9) di dalam dunia ideal semua warga negara dan bisnis akan memenuhi kewajiban mereka di bawah Undang-Undang Perpajakan. Ada 4 kewajiban utama dari warga negara dan bisnis, yaitu: (i) mendaftarkan diri ke otoritas pajak untuk tujuan pemenuhan kewajiban pajak; (ii) melaporkan Surat Pemberitahuan (SPT) tepat waktu; (iii) melaporkan kewajiban/utang pajak dengan benar; (iv) membayar pajak tepat waktu. Eurosai (2008) membedakan kepatuhan pajak menjadi 2, yaitu kepatuhan Wajib Pajak secara sukarela (voluntary compliance) dan kepatuhan Wajib Pajak setelah diintervensi oleh otoritas pajak (intervention compliance). Kepatuhan pajak sukarela indikatornya adalah (i) penyampaian infor- 
masi pajak kepada otoritas pajak secara tepat waktu; (ii) membayar pajak yang menjadi tanggungannya tepat waktu. Sedangkan kepatuhan pajak intervensi akan terjadi setelah otoritas pajak melakukan tindakan intervensi berupa pemeriksaan pajak dan langkah-langkah lainnya.

Di dalam Undang-Undang Perpajakan di Indonesia dan peraturan pelaksananya tidak dijelaskan secara eksplisit mengenai kriteria Wajib Pajak patuh. Namun pada ketentuan tentang restitusi pajak dikenal istilah Wajib Pajak patuh yang kemudian diubah menjadi Wajib Pajak dengan kriteria tertentu. Wajib Pajak dengan kriteria tertentu mendapatkan perlakuan khusus berupa kemudahan untuk melakukan restitusi pajak.Wajib Pajak dengan kriteria tertentu terakhir diatur dengan Peraturan Menteri Keuangan Indonesia Nomor 74/PMK.03/2012 tanggal 15 Mei 2012 tentang Tata Cara Penetapan dan Pencabutan Penetapan Wajib Pajak dengan Kriteria Tertentu dalam Rangka Pengembalian Pendahuluan Kelebihan Pembayaran Pajak.

Pada pasal 2 Peraturan Menteri Keuangan Indonesia Nomor 74/PMK. 03/2012 disebutkan untuk dapat ditetapkan sebagai Wajib Pajak dengan kriteria tertentu, Wajib Pajak harus memenuhi persyaratan sebagai berikut: (a) tepat waktu dalam menyampaikan Surat Pemberitahuan; (b) tidak mempunyai tunggakan pajak untuk semua jenis pajak, kecuali tunggakan pajak yang telah memperoleh izin mengangsur atau menunda pembayaran pajak; (c) Laporan Keuangan diaudit oleh Akuntan Publik atau lembaga pengawasan keuangan pemerintah dengan pendapat Wajar Tanpa Pengecualian selama 3 (tiga) tahun berturut-turut; dan (d) tidak pernah dipidana karena melakukan tindak pidana di bidang perpajakan berdasarkan putusan pengadilan yang telah mempunyai kekuatan hukum tetap dalam jangka waktu 5 (lima) tahun terakhir.

Kemudian pada pasal 3 Peraturan Menteri Keuangan Indonesia Nomor 74/PMK.03/2012 dijelaskan lebih lanjut mengenai persyaratan yang telah diatur dalam pasal 2. Hal pertama yang dijelaskan mengenai Wajib Pajak dinyatakan tepat waktu dalam penyampaian Surat Pemberitahuan jika memenuhi ketentuan: (i) penyampaian Surat Pemberitahuan Tahunan selama 3 (tiga) tahun pajak terakhir yang wajib disampaikan sampai dengan akhir tahun sebelum tahun penetapan Wajib Pajak dengan kriteria tertentu dilakukan tepat waktu; (ii) penyampaian Surat Pemberitahuan Masa yang terlambat dalam tahun terakhir sebelum tahun penetapan Wajib Pajak dengan kriteria tertentu untuk Masa Pajak Januari sampai November tidak lebih dari 3 (tiga) masa pajak untuk setiap jenis pajak dan tidak berturutturut; (iii) seluruh Surat Pemberitahuan Masa dalam tahun terakhir sebelum tahun penetapan Wajib Pajak Dengan kriteria tertentu untuk Masa Pajak Januari sampai November telah disampaikan; (iv) Surat Pemberitahuan Masa yang terlambat sebagaimana dimaksud pada huruf (ii) telah disampaikan tidak lewat dari batas waktu penyampaian Surat Pemberitahuan Masa untuk masa Pajak berikutnya. Hal kedua yang dijelaskan mengenai pemahaman Wajib Pajak tidak mempunyai tunggakan pajak adalah keadaan Wajib Pajak pada tanggal 31 Desember tahun sebelum penetapan sebagai Wajib Pajak dengan kriteria tertentu. Hal ketiga yang dijelaskan mengenai pengertian laporan keuangan diaudit oleh akuntan publik 
atau lembaga pengawasan keuangan pemerintah adalah laporan keuangan yang dilampirkan dalam Surat Pemberitahuan Tahunan Pajak Penghasilan yang wajib disampaikan selama 3 (tiga) tahun berturut-turut sampai dengan akhir tahun sebelum tahun penetapan Wajib Pajak dengan kriteria tertentu.

Jika dilihat dari uraian di atas, nampak bahwa apa yang diuraikan dalam Peraturan Menteri Keuangan Indonesia Nomor 74/PMK.03/2012 mengenai Wajib Pajak dengan kriteria tertentu tidak berbeda jauh dengan kriteria Wajib Pajak patuh yang ditetapkan oleh OECD (2008: 9). Kriteria Wajib Pajak seperti disebutkan dalam Peraturan Menteri Keuangan Indonesia Nomor 74/PMK.03/2012 ini juga tidak berbeda jauh jika dibandingkan dengan pendapat dari Kirchler and Wahl (2010) dan Eurosai (2008) mengenai Wajib Pajak dengan kepatuhan pajak bersifat sukarela (voluntary tax compliance) serta kepatuhan pajak menurut Gitaru (2017).

\section{METODE PENELITIAN}

Penelitian yang dilakukan merupakan penelitian kualitatif. Jenis penelitian kualitatif yang digunakan adalah penelitian survei. Penelitian survei bermaksud untuk mendapatkan informasi tentang satu atau lebih kelompok individu/orang dari sumbernya langsung guna mencapai tujuan penelitian.

Jenis data yang digunakan adalah data primer yaitu data yang dikumpulkan langsung dari sumber pertama. Data penelitian diperoleh melalui kuesioner yang diberikan kepada pengusaha mikro, kecil dan menengah di Jawa Timur, Indonesia.

Penelitian ini dilakukan dengan mengambil sampel sebanyak 82 usaha mikro, kecil dan menengah. Jenis usa- ha dari responden bermacam-macam, namun yang terbanyak adalah usaha makanan dan minuman.

Pengumpulan data penelitian dilakukan dengan menggunakan kuesioner. Kuesioner akan berisi pertanyaan yang disusun menjadi 2 kelompok pertanyaan. Kelompok pertama berisi pertanyaan awal yang dimaksudkan untuk mengumpulkan data terkait dengan profil responden. Sedangkan kelompok kedua berisi pertanyaan utama yang dimaksudkan untuk mendapatkan data yang memungkinkan peneliti mencapai tujuan penelitian.

Pada kelompok pertanyaan kedua akan diberikan pertanyaan untuk dapat menggali beberapa indikator yang diharapkan dapat menunjukkan indikasi kepatuhan pajak dari Wajib Pajak usaha mikro, kecil dan menengah. Beberapa data yang ingin didapat antara lain: (i) apakah Wajib Pajak mengetahui harus membayar Pajak Penghasilan atas usaha yang dimilikinya? (ii) apakah Wajib Pajak sudah mempunyai Nomor Pokok Wajib Pajak (NPWP)? (iii) apakah Wajib Pajak telah pernah membayar Pajak Penghasilan? (iv) apakah Wajib Pajak membayar Pajak Penghasilan dengan tarif final $1 \% / 0,5 \%$ atau dengan tarif umum? (v) apakah Wajib Pajak sudah pernah menyampaikan Surat Pemberitahuan (SPT) Tahunan Pajak Penghasilan? (vi) Jenis-jenis pajak apa saja yang sudah pernah dibayar oleh Wajib Pajak.

Data yang diperoleh dari kuesioner akan diolah lebih lanjut dalam bentuk tabulasi dan grafis untuk bisa menentukan jumlah dan persentase jawaban dari masing-masing pertanyaan. Kemudian data tersebut akan dianalisis lebih lanjut untuk dibuat simpulan dan rekomendasi. 


\section{HASIL PENELITIAN}

Dari jawaban pertanyaan awal diperoleh data mengenai profil responden yang menjadi sampel. Profil responden berdasarkan jenis kelamin nampak seperti terlihat Tabel 7 dan Gambar 1.

Tabel 7

Profil Responden Berdasarkan Jenis Kelamin

\begin{tabular}{|l|c|c|}
\hline $\begin{array}{c}\text { Jenis Kelamin } \\
\text { Responden }\end{array}$ & $\begin{array}{c}\text { Jumlah } \\
\text { Responden }\end{array}$ & $\begin{array}{c}\text { Persentase } \\
\text { (\%) }\end{array}$ \\
\hline Laki-laki & 11 & 13,41 \\
\hline Perempuan & 71 & 86,59 \\
\hline Total & 82 & 100 \\
\hline
\end{tabular}

Sumber: Data Diolah

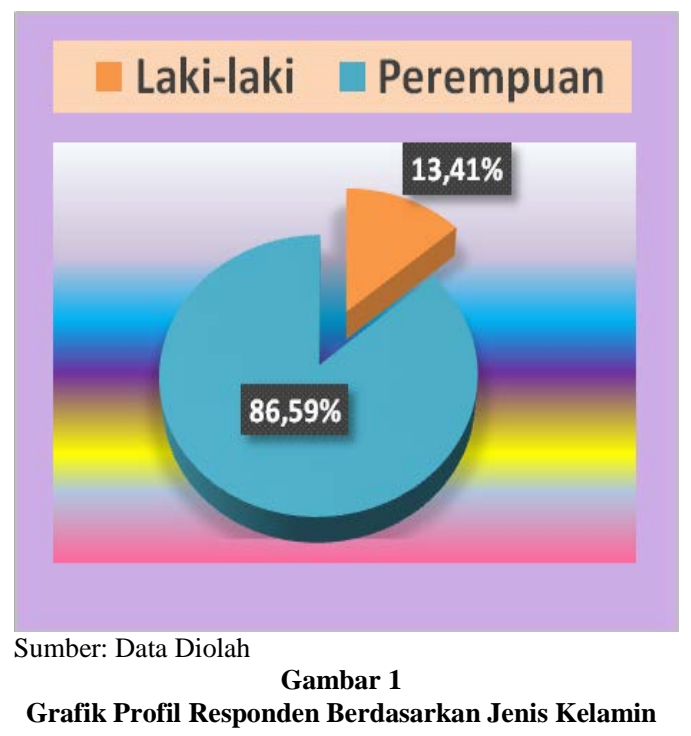

Data dari Tabel 7 dan Gambar 1 memperlihatkan bahwa sebagian besar pengusaha mikro, kecil dan menengah yang menjadi responden berjenis kelamin perempuan yaitu sebanyak 71 orang (86,59\%). Sedangkan responden dengan jenis kelamin laki-laki hanya sebanyak 11 orang $(13,41 \%)$. Hal ini sesuai dengan temuan dari IFC (2016) yang mengungkapkan bahwa seperti di banyak negara lain, di Jawa Timur 'perempuan cenderung memiliki bisnis yang lebih kecil'. Menerapkan definisi nasional UKM, survei yang dilakukan menemukan bahwa perempuan memiliki 52,9 persen dari usaha mikro, 50,6 persen usaha kecil dan 34 persen dari usaha menengah di daerah perkotaan. Jadi ada kecenderungan bisnis mikro dan kecil banyak dimiliki dan dijalankan oleh wanita. Profil responden berdasarkan usia seperti terlihat pada Tabel 8 dan Gambar 2.

Tabel 8

Profil Responden Berdasarkan Usia

\begin{tabular}{|l|c|c|}
\hline \multicolumn{1}{|c|}{ Usia Responden } & $\begin{array}{c}\text { Jumlah } \\
\text { Responden }\end{array}$ & $\begin{array}{c}\text { Persentase } \\
(\mathbf{\% )}\end{array}$ \\
\hline$<17$ tahun & 2 & 2,44 \\
\hline$\geq 17$ tahun dan $<25$ tahun & 6 & 7,32 \\
\hline$\geq 25$ tahun dan $<35$ tahun & 17 & 20,73 \\
\hline$\geq 35$ tahun dan $<45$ tahun & 24 & 29,27 \\
\hline$\geq 45$ tahun dan $<55$ tahun & 26 & 31,71 \\
\hline$\geq 55$ tahun & 7 & 8,54 \\
\hline Total & 82 & $100 *)$ \\
\hline
\end{tabular}

*) ada perbedaan selisih 0,01 karena pembulatan Sumber: Data Diolah

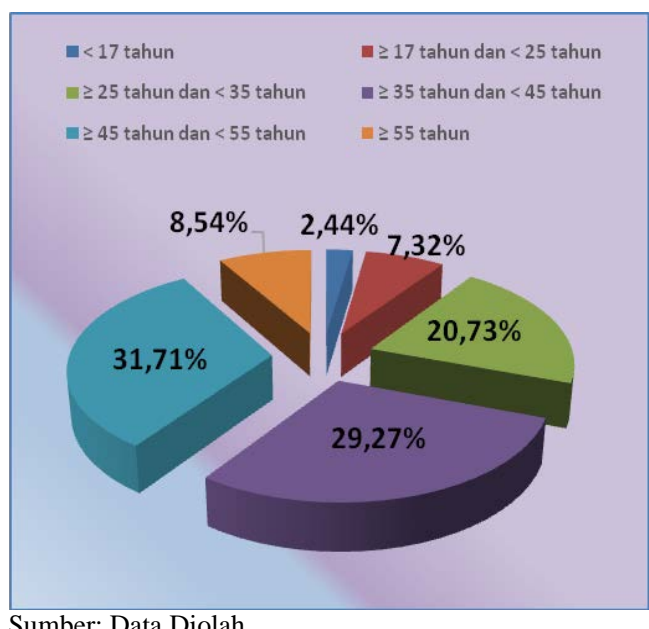

Sumber: Data Diolah

Gambar 2

Grafik Profil Responden Berdasarkan Jenis Kelamin

Dari Tabel 8 dan Gambar 2 nampak bahwa pengusaha mikro, kecil dan menengah terbanyak berada pada usia antara $\geq 25$ tahun dan $<55$ tahun, yaitu sebanyak 67 orang (81,71\%). Sedangkan yang berusia $<25$ tahun hanya ada 8 orang $(9,76 \%)$ dan berusia $\geq 55$ tahun ada 7 orang $(8,54 \%)$. Hal ini menunjukkan bahwa pengusaha mikro, kecil dan menengah masih didominasi yang memiliki usia produktif, yaitu antara $\geq 25$ tahun dan $<55$ tahun. Profil responden berdasarkan 
status perkawinan nampak seperti terlihat pada Tabel 9 dan Gambar 3.

Tabel 9

Profil Responden Berdasarkan Status Perkawinan

\begin{tabular}{|l|c|c|}
\hline $\begin{array}{c}\text { Status Perkawinan } \\
\text { Responden }\end{array}$ & $\begin{array}{c}\text { Jumlah } \\
\text { Responden }\end{array}$ & $\begin{array}{c}\text { Persentase } \\
\mathbf{( \% )}\end{array}$ \\
\hline Tidak Kawin & 17 & $20,73 \%$ \\
\hline Kawin & 59 & $71,95 \%$ \\
\hline Janda/Duda & 6 & $7,32 \%$ \\
\hline Total & 82 & 100 \\
\hline
\end{tabular}

Sumber: Data Diolah

= Tidak Kawin $=$ Kawin $=$ Janda/Duda

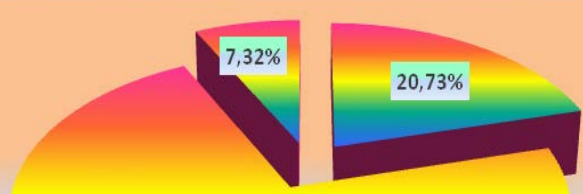

\section{$71,95 \%$}

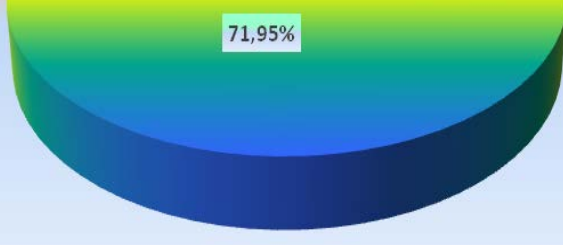

Sumber: Data Diolah

Gambar 3

Grafik Profil Responden Berdasarkan Status Perkawinan

Dari Tabel 9 dan Gambar 3 nampak bahwa status perkawinan responden didominasi yang berstatus kawin yaitu sebanyak 59 orang (71,95\%). Sedangkan yang berstatus tidak kawin sebanyak 17 orang (20,73\%) dan yang berstatus janda/duda sebanyak 6 orang (7,32\%). Profil dari responden berdasarkan tingkat pendidikannya nampak seperti terlihat pada Tabel 10 dan Gambar 4.

Tabel 10 Profil Responden Berdasarkan Tingkat Pendidikan

\begin{tabular}{|l|c|c|}
\hline $\begin{array}{c}\text { Tingkat Pendidikan } \\
\text { Responden }\end{array}$ & $\begin{array}{c}\text { Jumlah } \\
\text { Responden }\end{array}$ & $\begin{array}{c}\text { Persentase } \\
\text { (\%) }\end{array}$ \\
\hline SD & 9 & $10,98 \%$ \\
\hline SMP & 11 & $13,41 \%$ \\
\hline SMA & 24 & $29,27 \%$ \\
\hline Diploma & 5 & $6,10 \%$ \\
\hline S1 & 31 & $37,80 \%$ \\
\hline S2 & 2 & $2,44 \%$ \\
\hline Total & 82 & 100 \\
\hline Sumber: Data Diolah
\end{tabular}

믄

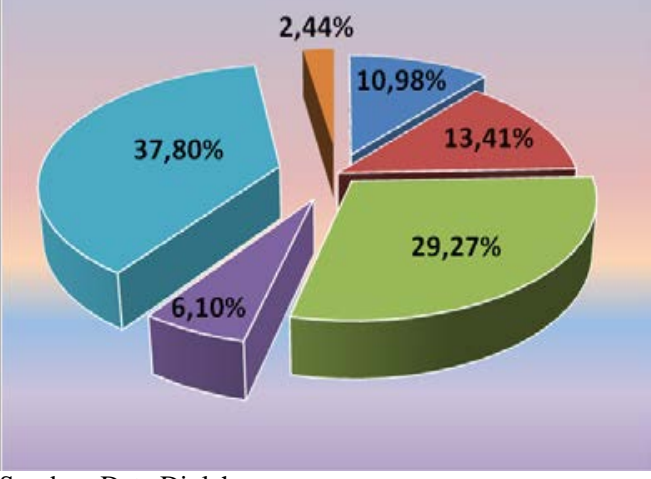

Sumber: Data Diolah

Gambar 4

Grafik Profil Responden Berdasarkan Tingkat Pendidikan

Dari Tabel 10 dan Gambar 4 nampak bahwa pengusaha mikro, kecil dan menengah yang memiliki tingkat pendidikan SD dan SMP sebanyak 20 orang (24,39\%). Sedangkan yang memiliki tingkat pendidikan SMA sebanyak 24 orang (29,27\%). Lalu yang memiliki tingkat pendidikan Diploma sebanyak 5 orang (6,10\%). Kemudian yang memiliki tingkat pendidikan S1 dan S2 masing-masing sebanyak 31 orang $(37,80 \%)$ dan 2 orang $(2,44 \%)$. Secara keseluruhan yang memiliki tingkat pendidikan SMA ke atas sebanyak 62 orang (75,61\%). Hal ini menunjukkan bahwa pengusaha mikro, kecil dan menengah di Indonesia sebagian besar sudah memiliki tingkat pendidikan yang cukup tinggi. Profil responden berdasarkan lama menjalankan usaha nampak seperti terlihat pada Tabel 11 dan Gambar 5.

Tabel 11

Profil Responden Berdasarkan Lama Usaha

\begin{tabular}{|l|c|c|}
\hline \multicolumn{1}{|c|}{ Usia Responden } & $\begin{array}{c}\text { Jumlah } \\
\text { Responden }\end{array}$ & $\begin{array}{c}\text { Persentase } \\
(\mathbf{\%})\end{array}$ \\
\hline$<1$ tahun & 8 & 9,76 \\
\hline$\geq 1$ tahun dan $<3$ tahun & 17 & 20,73 \\
\hline$\geq 3$ tahun dan $<5$ tahun & 18 & 21,95 \\
\hline$\geq 5$ tahun dan $<10$ tahun & 13 & 15,85 \\
\hline$\geq 10$ tahun dan $<15$ tahun & 15 & 18,29 \\
\hline$\geq 15$ tahun & 11 & 13,42 \\
\hline Total & 82 & 100 \\
\hline
\end{tabular}

Sumber: Data Diolah 


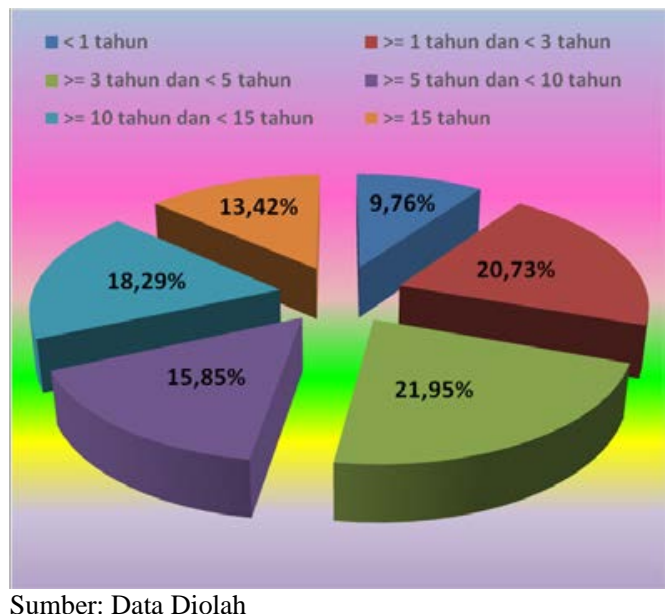

Gambar 5

Grafik Profil Responden Berdasarkan Lama Usaha

Dari Tabel 11 dan Gambar 5 nampak jumlah responden dengan lama usaha $<1$ tahun ada 8 orang (9,76\%). Kemudian yang mempunyai lama usaha $\geq 1$ tahun dan $<3$ tahun sebanyak 17 orang (20,73\%). Lalu yang mempunyai lama usaha $\geq 3$ tahun dan $<5$ tahun sebanyak 18 orang (21,95\%). Sedangkan yang mempunyai lama usaha $\geq 5$ tahun dan $<10$ tahun serta yang mempunyai lama usaha $\geq 10$ tahun dan $<15$ tahun masing-masing sebanyak 13 orang (15,85\%) dan 15 orang (18,29\%). Terakhir usaha mikro, kecil dan menengah yang memiliki lama usaha $\geq 15$ tahun sebanyak 11 orang (13,42\%). Data ini menunjukkan bahwa sebagian besar dari usaha mikro, kecil dan menengah sudah melakukan usahanya cukup lama, di mana sebagian besar atau majoritas usaha mikro, kecil dan menengah sudah mempunyai lama usaha $\geq 1$ tahun. Ada sebanyak 74 orang $(90,24 \%)$ usaha mikro, kecil dan menengah yang mempunyai lama usaha $\geq 1$ tahun. Sedangkan usaha mikro, kecil dan menengah yang lama usahanya $<1$ tahun hanya ada 8 orang (9,76\%). Profil mengenai jumlah keka- yaan usaha mikro, kecil dan menengah nampak seperti terlihat pada Tabel 12 dan Gambar 6.

Tabel 12

Profil Responden Berdasarkan Jumlah Kekayaan (Tidak Termasuk Tanah dan Bangunan)

\begin{tabular}{|c|c|c|}
\hline $\begin{array}{c}\text { Jumlah Kekayaan } \\
\text { (Rp.) }\end{array}$ & $\begin{array}{c}\text { Jumlah } \\
\text { Responden }\end{array}$ & $\begin{array}{c}\text { Persentase } \\
(\mathbf{\%})\end{array}$ \\
\hline$\leq 10$ juta & 65 & 79,27 \\
\hline$>10$ juta dan $\leq 25$ juta & 8 & 9,76 \\
\hline$>25$ juta dan $\leq 50$ juta & 3 & 3,66 \\
\hline$>50$ juta dan $\leq 200$ juta & 5 & 6,10 \\
\hline$>200$ juta dan $\leq 350$ juta & 0 & 0 \\
\hline$>350$ juta dan $\leq 500$ juta & 1 & 1,22 \\
\hline Total & 82 & $100 *)$ \\
\hline
\end{tabular}

*) ada perbedaan selisih 0,01 karena pembulatan Sumber: Data Diolah

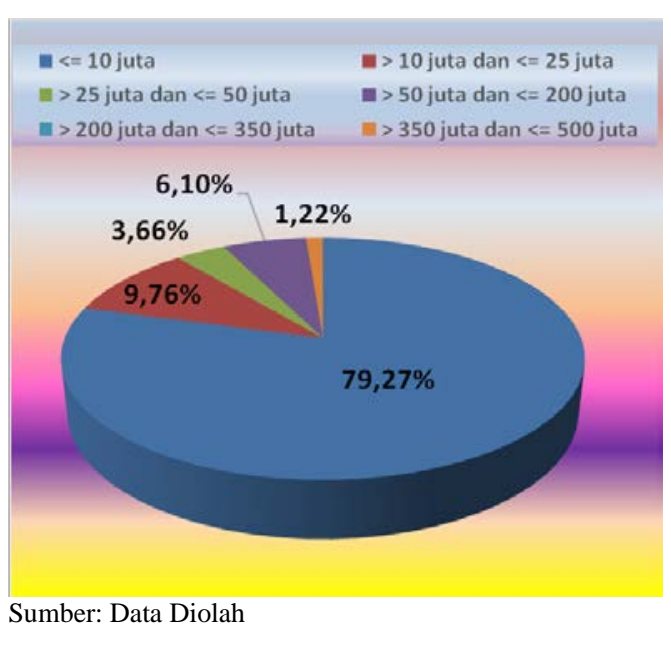

Gambar 6

Grafik Profil Responden Berdasarkan Jumlah Kekayaan (Tidak Termasuk Tanah dan Bangunan)

Dari Tabel 12 dan Gambar 6 nampak bahwa jumlah usaha mikro, kecil dan menengah yang mempunyai jumlah kekayaan $\leq$ Rp. 10.000.000,sebanyak 65 orang $(79,27 \%)$. Sedangkan yang mempunyai jumlah kekayaan $>$ Rp. 10.000.000,- dan $\leq$ Rp. 25.000.000,- sebanyak 8 orang. Kemudian yang mempunyai jumlah kekayaan > Rp. 25.000.000,- dan $\leq$ Rp. 50.000.000,- sebanyak 3 orang (3,66\%). Lalu yang mempunyai jumlah kekayaan > Rp. 50.000.000,- dan $\leq$ Rp. 200.000.000,- sebanyak 5 orang (6,10\%). Terakhir yang mempunyai 
jumlah kekayaan > Rp. 350.000.000,dan $\leq$ Rp. 500.000.000,- sebanyak 1 orang $(1,22 \%)$. Data ini menunjukkan sebagian besar usaha mikro, kecil dan menengah mempunyai jumlah kekayaan $\leq$ Rp. 10.000.000,- yaitu sebanyak 65 orang $(79,27 \%)$. Profil dari usaha mikro, kecil dan menengah berdasarkan jumlah penjualan per-tahun nampak seperti terlihat pada Tabel 13 dan Gambar 7.

Tabel 13

Profil Responden Berdasarkan Jumlah Penjualan per-tahun

\begin{tabular}{|l|c|c|}
\hline $\begin{array}{c}\text { Jumlah Penjualan } \\
\text { per-tahun (Rp.) }\end{array}$ & $\begin{array}{c}\text { Jumlah } \\
\text { Responden }\end{array}$ & $\begin{array}{c}\text { Persentase } \\
(\mathbf{\%})\end{array}$ \\
\hline$\leq 180$ juta & 71 & 86,59 \\
\hline$>180$ juta dan $\leq 300$ juta & 7 & 8,54 \\
\hline$>300$ juta dan $\leq 900$ juta & 1 & 1,22 \\
\hline$>900$ juta dan $\leq 1,5$ milyar & 2 & 2,44 \\
\hline$>1,5$ milyar dan $\leq 2,5$ milyar & 1 & 1,22 \\
\hline Total & 82 & $*) 100$ \\
\hline
\end{tabular}

*) ada perbedaan selisih 0,01 karena pembulatan Sumber: Data Diolah

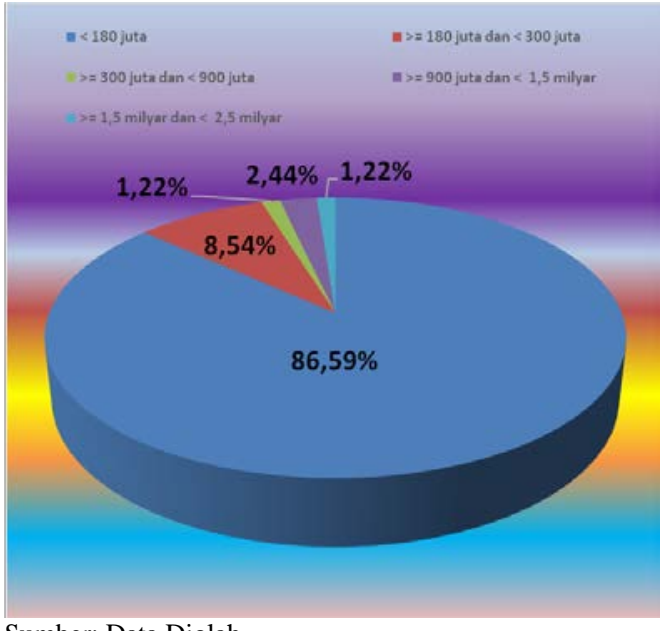

Sumber: Data Diolah

Gambar 7

Grafik Profil Responden Berdasarkan Jumlah Penjualan per-tahun

Dari Tabel 13 dan Gambar 7 nampak bahwa usaha mikro, kecil dan menengah yang mempunyai jumlah penjualan per-tahun sebesar $\leq \mathrm{Rp}$. 180.000.000,- sebanyak 71 orang (86,59\%). Kemudian yang mempunyai jumlah penjualan $>$ Rp. 180.000.000,- dan $\leq$ Rp. 300.000.000- sebanyak 7 orang (8,54\%). Lalu yang mempunyai jumlah penjualan $>$ Rp. 300.000.000,dan $\leq$ Rp. 900.000.000,- sebanyak 1 orang $(1,22 \%)$. Sedangkan yang mempunyai jumlah penjualan antara $>$ Rp. 900.000.000,- sampai dengan $\leq \mathrm{Rp}$. 1.500.000.000,- sebanyak 2 orang (2,44\%). Terakhir yang mempunyai jumlah penjualan antara $>$ Rp. 1.500.000.000,- sampai dengan $\leq \mathrm{Rp}$. 2.500.000.000,- sebanyak 1 orang (1,22\%). Profil usaha mikro, kecil dan menengah yang menjadi responden berdasarkan jenis usahanya nampak seperti terlihat pada Tabel 14 .

Tabel 14

Profil Responden Berdasarkan Jenis Usaha

\begin{tabular}{|l|c|c|}
\hline \multicolumn{1}{|c|}{ Jenis Usaha } & $\begin{array}{c}\text { Jumlah } \\
\text { Responden }\end{array}$ & $\begin{array}{c}\text { Persentase } \\
(\mathbf{\% )}\end{array}$ \\
\hline Aksesoris & 1 & 1,22 \\
\hline Bahan Bangunan & 1 & 1,22 \\
\hline Bahan Kimia & 1 & 1,22 \\
\hline Jasa Katering & 1 & 1,22 \\
\hline Foto Studio & 2 & 2,44 \\
\hline Laundry & 2 & 2,44 \\
\hline Pakaian & 3 & 3,66 \\
\hline Sepatu & 1 & 1,22 \\
\hline Penjahit & 1 & 1,22 \\
\hline Supplier & 2 & 2,44 \\
\hline Pet Shop & 1 & 1,22 \\
\hline Makanan/Minuman & 55 & 67,07 \\
\hline Kerajinan Tangan & 3 & 3,66 \\
\hline Rosela & 1 & 1,22 \\
\hline Toko & 3 & 3,66 \\
\hline Jasa Lainnya & 4 & 4,88 \\
\hline Total & 82 & $*) 100$ \\
\hline
\end{tabular}

*) ada perbedaan selisih 0,01 karena pembulatan

Sumber: Data Diolah

Dari Tabel 14 nampak jenis usaha dari usaha mikro, kecil dan menengah yang menjadi responden sangat bervariasi. Jenis usaha yang terbanyak adalah usaha makanan/minuman yang bila diperinci lagi ada usaha kue kering, kue basah, kacang bali, kerupuk, kulit kebab, keripik kebab, nasi kotak.

Pada bagian pertanyaan utama dari kuesioner ada 7 pertanyaan yang ditanyakan kepada responden. Dari 7 pertanyaan tersebut ada 6 pertanyaan yang hanya membutuhkan jawaban 
pilihan "Ya” atau “Tidak" dan 1 pertanyaan memberikan kemungkinan responden untuk memberikan 1 jawaban atau lebih. Pertanyaan pertama yang memerlukan jawaban "Ya" atau "Tidak" adalah "apakah anda mengetahui bahwa atas penghasilan yang diperoleh dari usaha, anda harus membayar Pajak Penghasilan?” Rekapitulasi jawaban dari pertanyaan pertama nampak seperti terlihat pada Tabel 15.

Tabel 15

Rekapitulasi Jawaban Pertanyaan Pertama

\begin{tabular}{|l|c|c|}
\hline Jawaban Pertanyaan & $\begin{array}{c}\text { Jumlah } \\
\text { Jawaban }\end{array}$ & $\begin{array}{c}\text { Persentase } \\
\text { (\%) }\end{array}$ \\
\hline Ya & 37 & 45,12 \\
\hline Tidak & 45 & 54,88 \\
\hline Total & 82 & 100 \\
\hline
\end{tabular}

Data dari Tabel 15 menunjukkan bahwa ada 37 orang $(45,12 \%)$ dari pengusaha mikro, kecil dan menengah yang mengetahui bahwa atas penghasilan dari usaha mereka harus membayar Pajak Penghasilan dan 45 orang (54,88\%) yang tidak mengetahui.

Pertanyaan kedua yang memerlukan jawaban "Ya" dan "Tidak" adalah "apakah anda mempunyai Nomor Pokok Wajib Pajak (NPWP)?” Rekapitulasi jawaban dari pertanyaan kedua nampak seperti terlihat pada Tabel 16.

Tabel 16

Rekapitulasi Jawaban Pertanyaan Kedua

\begin{tabular}{|l|c|c|}
\hline Jawaban Pertanyaan & $\begin{array}{c}\text { Jumlah } \\
\text { Jawaban }\end{array}$ & $\begin{array}{c}\text { Persentase } \\
\text { (\%) }\end{array}$ \\
\hline Ya & 31 & 37,80 \\
\hline Tidak & 51 & 62,20 \\
\hline Total & 82 & 100 \\
\hline
\end{tabular}

Sumber: Data Diolah

Data dari Tabel 16 menunjukkan bahwa ada 31 orang $(37,80 \%)$ dari pengusaha mikro, kecil dan menengah mempunyai Nomor Pokok Wajib Pajak (NPWP) dan 51 orang (62,20\%) tidak mempunyai Nomor Pokok Wajib Pajak (NPWP).
Pertanyaan ketiga yang memerlukan jawaban "Ya" dan "Tidak" adalah "apakah anda telah pernah membayar Pajak Penghasilan atas kegiatan usaha anda?” Rekapitulasi jawaban dari pertanyaan ketiga nampak seperti terlihat pada Tabel 17.

Tabel 17

Rekapitulasi Jawaban Pertanyaan Ketiga

\begin{tabular}{|l|c|c|}
\hline Jawaban Pertanyaan & $\begin{array}{c}\text { Jumlah } \\
\text { Jawaban }\end{array}$ & $\begin{array}{c}\text { Persentase } \\
\text { (\%) }\end{array}$ \\
\hline Ya & 18 & 21,95 \\
\hline Tidak & 64 & 78,05 \\
\hline Total & 82 & 100 \\
\hline
\end{tabular}

Sumber: Data Diolah

Data dari Tabel 17 menunjukkan bahwa ada 18 orang (21,95\%) dari pengusaha mikro, kecil dan menengah yang telah pernah membayar Pajak Penghasilan dan 64 orang (78,05\%) yang tidak pernah membayar Pajak Penghasilan dari kegiatan usahanya.

Pertanyaan keempat yang memerlukan jawaban "Ya" dan "Tidak" adalah "apakah anda membayar Pajak Penghasilan dengan tarif $1 \% / 0,5 \%$ dari penjualan?” Rekapitulasi jawaban dari pertanyaan keempat nampak seperti terlihat pada Tabel 18.

Tabel 18

Rekapitulasi Jawaban Pertanyaan Keempat

\begin{tabular}{|l|c|c|}
\hline Jawaban Pertanyaan & $\begin{array}{c}\text { Jumlah } \\
\text { Jawaban }\end{array}$ & $\begin{array}{c}\text { Persentase } \\
(\%)\end{array}$ \\
\hline Ya & 18 & 21,95 \\
\hline Tidak & 64 & 78,05 \\
\hline Total & 82 & 100 \\
\hline
\end{tabular}

Sumber: Data Diolah

Data dari Tabel 18 menunjukkan bahwa ada 18 orang (21,95\%) dari pengusaha mikro, kecil dan menengah yang telah pernah membayar Pajak Penghasilan dengan tarif $1 \% / 0,5 \%$ dari penjualan dan 64 orang (78,05\%) yang tidak pernah membayar Pajak Penghasilan dengan tarif 1\%/0,5\% dari penjualan dari kegiatan usahanya.

Pertanyaan kelima yang memerlukan jawaban "Ya" dan "Tidak" 
adalah "apakah anda membayar Pajak Penghasilan dengan tarif progresif dari laba kena pajak?” Rekapitulasi jawaban dari pertanyaan kelima nampak seperti terlihat pada Tabel 19.

Tabel 19

Rekapitulasi Jawaban Pertanyaan Kelima

\begin{tabular}{|l|c|c|}
\hline Jawaban Pertanyaan & $\begin{array}{c}\text { Jumlah } \\
\text { Jawaban }\end{array}$ & $\begin{array}{c}\text { Persentase } \\
(\%)\end{array}$ \\
\hline Ya & 0 & 0 \\
\hline Tidak & 82 & 100 \\
\hline Total & 82 & 100 \\
\hline
\end{tabular}

Sumber: Data Diolah

Data dari Tabel 19 menunjukkan bahwa semua (100\%) pengusaha mikro, kecil dan menengah tidak pernah membayar Pajak Penghasilan dengan tarif progresif dari laba kena pajak.

Pertanyaan keenam yang memerlukan jawaban "Ya" dan "Tidak" adalah "apakah anda mengisi dan menyampaikan SPT Tahunan Pajak Penghasilan?” Rekapitulasi jawaban dari pertanyaan keenam nampak seperti terlihat pada Tabel 20.

\section{Tabel 20}

Rekapitulasi Jawaban Pertanyaan Keenam

\begin{tabular}{|l|c|c|}
\hline Jawaban Pertanyaan & $\begin{array}{c}\text { Jumlah } \\
\text { Jawaban }\end{array}$ & $\begin{array}{c}\text { Persentase } \\
(\%)\end{array}$ \\
\hline Ya & 15 & 18,29 \\
\hline Tidak & 67 & 81,71 \\
\hline Total & 82 & 100 \\
\hline \multicolumn{2}{|l}{}
\end{tabular}

Data dari Tabel 20 menunjukkan bahwa ada 15 orang (18,29\%) dari pengusaha mikro, kecil dan menengah yang mengisi dan menyampaikan SPT Tahunan Pajak Penghasilan dan 67 orang $(81,71 \%)$ yang tidak mengisi dan menyampaikan SPT Tahunan Pajak Penghasilan.

Pertanyaan ketujuh atau terakhir adalah pertanyaan yang memungkinkan responden untuk memilih lebih dari 1 jawaban dari banyak pilihan jawaban yang disediakan. Pertanyaan ketujuh adalah "Pajak yang pernah anda bayar adalah?” Rekapitulasi ja- waban dari pertanyaan ketujuh nampak seperti terlihat pada Tabel 21.

Tabel 21

Rekapitulasi Jawaban Pertanyaan Ketujuh

\begin{tabular}{|l|c|c|}
\hline Jawaban Pertanyaan & $\begin{array}{c}\text { Jumlah } \\
\text { Jawaban }\end{array}$ & $\begin{array}{c}\text { Persentase } \\
\text { (\%) }\end{array}$ \\
\hline Pajak Penghasilan & 18 & 21,95 \\
\hline $\begin{array}{l}\text { Pajak Kendaraan } \\
\text { Bermotor (PKB) }\end{array}$ & 59 & 71,95 \\
\hline $\begin{array}{l}\text { Pajak Bumi dan } \\
\text { Bangunan (PBB) }\end{array}$ & 58 & 70,73 \\
\hline Pajak Lain-lain & 0 & 0 \\
\hline
\end{tabular}

Sumber: Data Diolah

Data dari Tabel 21 menunjukkan bahwa ada 18 orang $(21,95 \%)$ dari pengusaha mikro, kecil dan menengah yang membayar Pajak Penghasilan, ada 59 orang (71,95\%) yang membayar Pajak Kendaraan Bermotor (PKB) dan ada 58 orang $(70,73 \%)$ yang membayar Pajak Bumi dan Bangunan (PBB) serta tidak ada yang membayar pajak lainnya.

\section{PEMBAHASAN}

Undang-Undang UMKM (Undang-Undang Nomor 20 Tahun 2008 tentang Usaha Mikro, Kecil dan Menengah) menyatakan penentuan suatu usaha menjadi kelompok usaha mikro, kecil dan menengah didasarkan pada jumlah kekayaan dan jumlah penjualan. Bila mengacu pada ketentuan jumlah kekayaan, maka usaha mikro, kecil dan menengah yang menjadi responden ada 76 usaha yang tergolong kelompok usaha mikro dan sisanya sebanyak 6 usaha tergolong kelompok usaha kecil. Sedangkan jika ditinjau dari jumlah penjualan, maka ada sebanyak 78 usaha yang tergolong usaha mikro dan sisanya sebanyak 4 usaha tergolong usaha kecil. Jadi tidak ada responden dengan kategori usaha menengah.

Jumlah usaha mikro, kecil dan menengah yang mengetahui bahwa mereka harus membayar Pajak Peng- 
hasilan atas kegiatan usaha yang dilakukan sebanyak 45,12\%, sedangkan sisanya sebanyak $54,88 \%$ tidak mengetahui bahwa mereka harus membayar Pajak Penghasilan atas usaha yang dijalankan. Hal ini menunjukkan bahwa pengetahuan Wajib Pajak pengusaha mikro, kecil dan menengah mengenai pajak, khususnya Pajak Penghasilan masih sangat minim. Oleh karena itu usaha sosialisasi intensif mengenai kesadaran untuk membayar pajak, khususnya Pajak Penghasilan masih sangat dibutuhkan.

Untuk mengetahui tingkat kepatuhan Wajib Pajak dari kalangan usaha mikro, kecil dan menengah terhadap pemenuhan kewajiban perpajakan, khususnya Pajak Penghasilan, penelilitian ini menggunakan 3 indikator utama yang diharapkan dapat mengukur tingkat kepatuhan Wajib Pajak. Tiga indikator utama tersebut, yaitu kepemilikan Nomor Pokok Wajib Pajak (NPWP), kepatuhan membayar Pajak Penghasilan dan kepatuhan menyampaikan Surat Pemberitahuan (SPT) Tahunan Pajak Penghasilan. Informasi lain yang akan coba digali untuk melengkapi penelitian adalah mengenai tingkat pengetahuan dari usaha mikro, kecil dan menengah tentang pajak, khususnya Pajak Penghasilan serta informasi jenis pajak lainnya yang dibayar oleh Wajib Pajak.

Ditinjau dari kepemilikan Nomor Pokok Wajib Pajak (NPWP), jumlah usaha mikro, kecil dan menengah yang mempunyai Nomor Pokok Wajib Pajak masih sangat sedikit. Hanya ada $37,80 \%$ usaha mikro, kecil dan menengah yang memiliki Nomor Pokok Wajib Pajak, sedangkan sisanya sebesar $62,20 \%$ belum memiliki Nomor Pokok Wajib Pajak. Hal ini menunjukkan bahwa kegiatan sosialisasi mengenai kesadaran untuk patuh memenuhi kewajiban perpajakan, khususnya di kalangan usaha mikro, kecil dan menengah guna memiliki Nomor Pokok Wajib Pajak (NPWP) harus terus digencarkan.

Sedangkan bila ditinjau dari kepatuhan untuk membayar Pajak Penghasil hanya ada 21,95\% yang pernah membayar Pajak Penghasilan dan sisanya sebanyak $78,05 \%$ tidak pernah membayar Pajak Penghasilan. Keseluruhan Wajib Pajak membayar Pajak Penghasilan dengan tarif final 1\%/ 0,5\% berdasarkan ketentuan dari Peraturan Pemerintah Nomor 46 Tahun 2013 dan Peraturan Pemerintah Nomor 23 Tahun 2018. Jumlah Wajib Pajak yang sudah membayar Pajak Penghasilan ini sangat sedikit.

Kemudian jika ditinjau dari sudut kepatuhan mengisi dan menyampaikan Surat Pemberitahuan (SPT) Tahunan Pajak Penghasilan hanya ada 18,29\% yang menyampaikan Surat Pemberitahuan (SPT) Tahunan Pajak Penghasilan, sedangkan sisanya sebanyak $81,71 \%$ tidak menyampaikan Surat Pemberitahuan (SPT) Tahunan. Data ini lagi-lagi menunjukkan bahwa tingkat kepatuhan Wajib Pajak dari kalangan usaha mikro, kecil dan menengah untuk mengisi dan menyampaikan Surat Pemberitahuan (SPT) Tahunan Pajak Penghasilan masih sangat rendah.

Data lainnya yang diperoleh dari penelitian ini yaitu berkaitan dengan kepatuhan membayar jenis pajak lainnya selain Pajak Penghasilan. Untuk Pajak Kendaraan Bermotor (PKB) jumlah Wajib Pajak yang patuh membayar sebanyak 71,95\% dan untuk Pajak Bumi dan Bangunan (PBB) jumlah Wajib Pajak yang patuh membayar sebanyak 70,73\%. Ini menun- 
jukkan bahwa tingkat kepatuhan cukup tinggi. Jumlah yang tidak membayar Pajak Kendaraan Bermotor (PKB) dan Pajak Bumi dan Bangunan (PBB) sekitar 20\%-30\% sebagian mungkin disebabkan karena yang bersangkutan tidak memiliki kendaraan bermotor dan atau tanah dan atau bangunan. Jadi mungkin hanya ada sebagian kecil saja yang benar-benar tidak patuh membayar pajak.

\section{SIMPULAN}

Hasil penelitian menunjukkan bahwa tingkat kepatuhan dari usaha mikro, kecil dan menengah dalam memenuhi kewajiban Pajak Penghasilan masih sangat rendah. Ini ditunjukkan dari 3 indikator utama yang diteliti, yaitu kepemilikan Nomor Pokok Wajib Pajak (NPWP), kepatuhan membayar Pajak Penghasilan serta kepatuhan mengisi dan menyampaikan Surat Pemberitahuan (SPT) Tahunan Pajak Penghasilan.

Dari sudut kepemilikan Nomor Pokok Wajib Pajak hanya ada 37,80\% usaha mikro, kecil dan menengah yang mempunyai Nomor Pokok Wajib Pajak dan sisanya sebanyak 62,20\% tidak mempunyai Nomor Pokok Wajib Pajak. Dari sudut kepatuhan membayar Pajak Penghasilan, hanya ada 21,95\% yang pernah membayar Pajak Penghasilan dan sisanya sebanyak 78,05\% tidak pernah membayar Pajak Penghasilan. Kemudian dari sudut kepatuhan mengisi dan menyampaikan Surat Pemberitahuan (SPT) Tahunan Pajak Penghasilan hanya ada 18,29\% yang mengisi Surat Pemberitahuan (SPT) Tahunan Pajak Penghasilan dan sisanya sebanyak $81,71 \%$ tidak mengisi dan menyampaikan Surat Pemberitahuan (SPT) Tahunan. Jika ditinjau dari sudut jumlah Wajib Pajak yang pernah membayar Pajak Penghasilan, maka ada 83,33\% dari Wajib Pajak yang pernah membayar Pajak Penghasilan yang menyampaikan Surat Pemberitahuan (SPT) Tahunan Pajak Penghasilan.

Kemudian jika ditinjau dari sudut kepatuhan membayar pajak lainnya, Wajib Pajak cukup baik tingkat kepatuhannya. Ada sebanyak 71,95\% yang patuh membayar Pajak Kendaraan Bermotor (PKB) dan ada 70,73\% yang patuh membayar Pajak Bumi dan Bangunan (PBB).

Hasil penelitian juga menunjukkan bahwa cukup banyak usaha mikro, kecil dan menengah yang belum memahami bahwa atas usaha yang dijalankan harus membayar Pajak Penghasilan. Usaha mikro, kecil dan menengah yang tidak mengerti bahwa atas usaha yang dijalankan harus membayar Pajak Penghasilan ada sebanyak $54,88 \%$.

\section{SARAN}

Mengingat masih kurangnya pemahaman Wajib Pajak dari kalangan usaha mikro, kecil dan menengah mengenai kewajiban membayar Pajak Penghasilan atas usaha yang dijalankan, maka sosialisasi mengenai kewajiban membayar dan melaporkan Pajak Penghasilan harus diintensifkan secara terus-menerus.

Usaha-usaha lain yang bersifat persuasif dan pembinaan harus dilakukan secara terus-menerus dan berkelanjutan ke usaha mikro, kecil dan menengah dalam rangka meningkatkan kepatuhan membayar Pajak Penghasilan dan melaporkannya agar tingkat kepatuhan membayar Pajak Penghasilan di kalangan usaha mikro, kecil dan menengah yang masih rendah dapat ditingkatkan. 


\section{DAFTAR KEPUSTAKAAN}

Agbemava, Edinam, Godwin Ahiase, Edward Sedzro, Thomas Clarkson Adade, Albert K. Bediako, Israel Kofi Nyarko and Matthew Brains Kudo, 2016, Assessing The Effects of Sound Financial Statement Preparation on The Growth of Small and Medium-Scale Enterprises, The International Journal of Business \& Management, Vol. 4, Issue 3, page 104-111.

Arachi, Giampaolo and Alessandro Santoro, 2007, Tax Enforcement for SMEs: Lessons from The Italian Experience, e-Journal of Tax Research, Vol. 5, No. 2 (Michigan Issue), page 225-243.

Atawodi, Ojochogwu Winnie and Stephen Aanu Ojeka1, 2012, Factors That Affect Tax Compliance among Small and Medium Enterprises (SMEs) in North Central Nigeria, International Journal of Business and Management Vol. 7, No. 12, page 87-96.

Başçı, Sıdıka and Ayşegül Durucan, 2017, A Review of Small and Medium Sized Enterprises (SMEs) in Turkey, Yildiz, Social Science Review.

Bellefleur, Daniel, Zahra Murad and Patrick Tangkau, 2012, A Snapshot of Indonesian Entrepreneurship and Micro, Small and medium Sized Enterprise Development, United States Agency International Development (USAID).

Berisha, Gentrit and Justina Shiroka Pula, 2015, Defining Small and Medium Enterprises: A Critical Review, Academic Journal Of Bu- siness, Administration, Law and Social Sciences, Vol. 1, No. 1, page 17-28.

European Commission, 2015, User Guide to the SME Definition, Publications Office of the European Union, Luxembourg.

Eurosai, 2008, Benchmarking of Tax Administrations, Report of The Eurosai Study Group.

Giataru, Kelvin, 2017, The Effect of Taxpayer Education on Tax Compliance in Kenya (A Case Study of SME's in Nairobi Central Business District), University of Nairobi, School of Economics.

Herman, Emilia, 2012, SMEs and Their Effect on The Romanian Employment, Procedia Economics and Finance, Vol. 3, page 290297.

IFC, 2016, Women-owned SMEs in Indonesia: A Golden Opportunity for Local Financial Institutions, Market Research Study.

Keskin, Hidayet, Canan Şentürk, Onur Sungur and Hakan M. Kiriş, 2010, The Importance of SMEs in Developing Economies, 2nd International Symposium on Sustainable Development, June 2010, Sarajevo.

Kirchler, Erich and Ingrid Wahl, 2010, Tax Compliance Inventory: TAX-I Voluntary Tax Compliance, Enforced Tax Compliance, Tax Avoidance, and Tax Evasion, $\mathrm{J}$ Econ Psychol, Vol. 31, No. 3, page 331346.

OECD, 2008, Monitoring Taxpayers' Compliance: A Practical Guide Based on Revenue Body Experience, 
Forum on Tax Administration: Compliance Sub-Group, Final Report, Centre for Tax Policy and Administration.

OECD, 2010, SMEs Entrepreneurship and Innovation, OECD Studies on SMEs and Entrepreneurship.

OECD, 2015, Taxation of SMEs in OECD and G20 Countries, OECD Tax Policy Studies, No. 23, OECD Publishing, Paris.

Ponorica, Andreea Gabriela and Ahmed H. Juhi Al-Saedi, 2015, The Importance of Taxation Systems for SME Tax Compliance, Proceedings of The 9th International Management Conference, Management and Innovation for Competitive Advantage, Bucharest, Rumania.

Şentürk, Canan, Hidayet Keskin, Yasemen Kiriș, Perihan Türköz and Hakan M. Kiriş, 2008, Can SMEs in Developing Countries Resist Crisis? An Analysis on Turkish and Albanian Cases, ICBS 2008.

Swistak, Arthur, 2016, Tax Penalties in SME Tax Compliance, Financial Theory and Practice, Vol. 40, No. 1, page 129-147.
Tambunan, Tulus and Liu Xiang Feng, 2008, SME Development in Indonesia and China.

Undang-Undang Nomor 20 Tahun 2008 tentang Usaha Mikro, Kecil dan Menengah.

Vandenberg, Paul, Pornpinun Chantapacdepong and Naoyuki Yoshino, 2013, Small Firms, Market Failures, and Government Policy, Asian Development Bank Institute, Tokyo.

Yon, Rachel and Daniel Evans, 2011, The Role of Small and Medium Enterprises in Frontier Capital Markets, Network Science Center, West Point.

Yoshino, Naoyuki and Farhad Taghizadeh-Hesary, 2017, Solutions for Small and Medium-Sized Enterprises' Difficulties in Accessing Finance: Asian Experiences, ADBI Working Paper Series Nomor 768, Asian Development Bank Institute, Tokyo. 